\title{
Effect of Growth Retardants on Shoot and Root Development of Stevia(Steviarebaudiana Bertoni) Plant Grown in Vitro
}

\author{
Reda El-Said Abo El-Fadl \\ Tissue Culture Unit, Department of Genetic Resources, Ecology and Dry Land Agriculture Division, Desert \\ Research Center, Cairo, Egypt
}

\begin{abstract}
Stevia rebaudianaBertoni is a natural sweetener herb, which is promising in food and pharmaceutical production. In Egypt, the gap between sugar production and consumption represents a serious problem, in order to close this gap; Stevia could be cultivated in the Egyptian environmental conditions. The objective of this study was to evaluate the effect of paclobutrazol(PBZ) and ethephon (ET) on shooting and rooting of stevia plant in vitroto improve the survival and growth of Stevia plantlets during acclimatization.The highest shoot number (48.0 shoots/explant) and the highest number of leaves (7.34) were recorded on MS medium containing $0.1 \mathrm{mg} / \mathrm{l}$ PBZ. Whereas, the highest shoot length $(7.36 \mathrm{~cm})$ was obtained on MS medium without supplementation withPBZ or ET. The highest fresh and dry weights of shoots was recorded on MS medium containing $0.5 \mathrm{mg} / \mathrm{l} P B Z$, which gave 2.83 and $0.39 \mathrm{~g}$, respectively. The highest number of roots (8.44 roots/shoot) was obtained with $0.1 \mathrm{mg} / \mathrm{PBZ}$. Also, this study indicates that PBZ or ET increased chlorophyll a, chlorophyll b, carotenoids and carbohydrates content in the plant. PBZ and ET had significant effect on thesurvival of plants ex vitro, which recorded 85 and $75 \%$, respectively.
\end{abstract}

Keywords: Stevia, microprpagation, paclobutrazol,ethephon

\section{Introduction}

Stevia rebaudianaBertoni(Stevia) is a perennial herb, belonging to family Asteraceae.The leaves of Stevia are source of diterpene glycosides, such as stevioside and rebaudiosides, which are estimated to be 100300 times sweeter than sucrose (Tanaka, 1982). It is being commercially cultivated in China, Taiwan, Thailand, Korea, Japan, India and Malaysia (Jain et al., 2009).Stevia extracts have no reported side effects and can be used as an alternative to sugar and other synthetic sweeteners (Thiyagarajan and Venkatachalam, 2012).Stevioside from Stevia is regenerated as a valuable natural sweetening agent due to its relatively good taste and chemical stability. It is of special interest to diabetic persons with hyperglycemia and the diet conscious (Toyoda et al., 1997 andArpitaet al.,2011). Summon et al. (2008) reported that Stevia also can act as an antimicrobial in pharmacological studies and according to Debnath (2008), the crude leaf chloroform extract of leaves can inhibit Staphylococcus aureus, Streptococcus mutans, Bacillus subtilis and Escherichia coli. Secondary metabolites in Stevia are used as functional component in the food industries (Savita et al., 2004).The largescale cultivation of Stevia plants is important for the human health because of the many benefits it gives. Seed germination is often poor and rates are below 10\% (Miyazaki and Wantenabe, 1974). Propagation using the seed also causes great variability on stevioside level and composition (Nakamura and Tamura, 1985). The stem cutting method has limitations, such as low number of new plants and destruction of the donor plant. Micropropagation or in vitro culture appears to be the best method to overcome those problems and has the potential to produce large quantity of stevia plantlets in short time(Uddinet al., 2006). The tissue culture is also a powerful tool that can accelerate the genetic breeding (Alveset al., 2011).

The quality ofinvitroproducedplants should be at least the same as that of traditionally propagated planting materials, the plantlets have less developed cuticle, epicuticular waxes and functional stomatal apparatus, causing high stomatal and cuticular transpiration or a transplantation shock during the first step of theacclimatization process (Hazarika, 2006; Chandra et al., 2010 and Kumar and Rao, 2012).It is therefore important to use in the micropropagation procedure such treatments that increase the ability to survive the acclimatization stress and enable a quick adaptation to heterotrophy. Growth retardants are known to be effective in improving survival of plantlets after their transfer to the soil(Eliassonet al., 1994). Plant growth retardants are commonly used to inhibit stem elongation of many ornamental plants, they act by inhibiting cell division in the sub-apical meristem of the shoot or by inhibiting cell elongation (Grossman, 1992).Paclobutrazol(PBZ) \{2RS, 3RS)-(4-chlorophenyl)-4,4-dimethyl-2-(1H,1,2,4-triazol-1-yl)-pentan-3-01 \} is one of the growth retardants, which inhibits kaurene oxidase and thus blocks the oxidative reactions from ent-kaurene to entkaurenoic acid in the pathway leading to gibberellic acid (Graebe, 1987).PBZ is among the compounds that can positively affect the acclimatization of microplants (Roberts et al., 1992andSopheret al., 1999).Ethephon (ET) \{(2-chloroethyl) phosphonic acid \} is a growth retardant that release ethylene $\left(\mathrm{C}_{2} \mathrm{H}_{4}\right)$, chlorine $\left(\mathrm{Cl}^{-}\right)$and hydrogen phosphate $\left(\mathrm{H}_{2} \mathrm{PO}_{4}\right)$ on application and is known to inhibit internode elongation, induce branching(Gladyet al., 
2007).Ethephon is an ethylene-releasing compound, and it is widely used as a plant growth regulator. The effect of the application of exogenous gaseous ethylene or ET solution varies with plant species, chemical concentrations, timing and duration of application. ET regulates phases of plant growth and development by application to various growth sites (Kidd and James, 1991).The objective of this study was to assess the influence of two plant growth retardants (paclobutrazol and ethephon) on shoots and root growth to improve the ex vitro survival and growth of Stevia plantlets during acclimatization.

\section{Plant material}

\section{Materials And Methods}

Stevia plants were obtained from the Sugar Crop Institute, Agricultural Research Center, Giza, Egypt. The plants were maintained under greenhouse conditions at the Desert Research Center, Cairo, Egypt, for at least three months prior to removal of materials for culture.

\section{Explant sterilization}

Shoot tips and stem nodal segments were placed under running tap water for $30 \mathrm{~min}$, then surface sterilized under complete aseptic conditions. Stem nodal segments were cut into $2-3 \mathrm{~cm}$ and then were soaked in a $25 \%(\mathrm{v} / \mathrm{v})$ of commercial bleach solution (1.25\% sodium hypochlorite) for $30 \mathrm{~min}$ with gentle agitation. Shoot tips were soaked in $20 \%(\mathrm{v} / \mathrm{v})$ commercial bleach solution (1.0\% sodium hypochlorite) for $15 \mathrm{~min}$. Finally, the explants were rinsed three times in sterile distilled water.

\section{Culture medium and conditions}

All the surface sterilized explants were cultured on a full strength basal Murashige and Skoog (MS) medium (Murashige and Skooge, 1962) (Duchefa, Haarlem, Netherlands) supplemented with $30 \mathrm{~g} / \mathrm{l}$ sucrose. The $\mathrm{pH}$ of the medium was adjusted to 5.7-5.8 before being solidified with $3.0 \mathrm{~g} / \mathrm{l}$ phytagel (Duchefa, Haarlem, Netherlands), then autoclaved at a pressure of $1.06 \mathrm{~kg} / \mathrm{cm}^{2}$ and $121^{\circ} \mathrm{C}$ with a $16-\mathrm{h}$ photoperiod under cool white fluorescent tubes.

\section{Effect of PBZ and ET on shoot multiplication}

Explants were established in vitro on MS medium supplemented with $1 \mathrm{mg} / \mathrm{l}$ kinetin.After, four weeks, the in vitro established shoots were transferred to be multiplied on MS medium supplemented with $2 \mathrm{mg} / \mathrm{l} 6$ benzyl adenin (BA) with four concentrations of PBZ or ET (0.1, 0.5, 1.0 and $2 \mathrm{mg} / \mathrm{l}$ ). Average number of shoots per explant, average shoot length $(\mathrm{cm})$, average number of leaves per shoot and fresh and dry weights of shoots $(\mathrm{g})$ were recorded after six weeks for eight subcultures.

\section{Effect of $P B Z$ and $E T$ on root formation}

Single shoots of Stevia of length of $2 \mathrm{~cm}$ were excised and transferred to MS medium supplemented with $2 \mathrm{mg} / \mathrm{l}$ indole butyric acid (IBA) and the same concentrations of PBZ or ET $(0.1,0.5,1.0$, and $2.0 \mathrm{mg} / \mathrm{l})$. Data were recorded in terms of percentage of rooting, average number of roots/shoot and average root length (cm) after six weeks from culturing.

\section{Acclimatization}

After six weeks, the plantlets were removed from the rooting media, washed in water to remove phytagel and soaked in fungicide solution (maxim) for $30 \mathrm{~s}$, and then transferred to plastic pots containing equal volumes of sterile mixture of peat moss, perlite and sand. The transplanted plants were covered with plastic bags to maintain humidity, placed in greenhouse; the plastic bags were opened gradually. The survival percentage of the in vitro propagated plants was evaluated after eight weeks.

\section{Determination of photosynthetic pigments}

Chlorophyll a and b and carotenoids were extracted from shoots and estimated according to Fadeel's method (1962) and Von Wettstein (1957).The testing procedures were carried out at low light to protect the pigments from breakdown. Fresh leaf samples $(0.5 \mathrm{~g})$ were homogenized in mortar with $85 \%$ acetone according to Fadeel's method (1962). The optical densities were measured spectrophotometrically using Pharamisia LKB Novasspec at 622, 644 and $440 \mathrm{~nm}$. The pigment concentrations were calculated using Wettstain's formula (Von Wettstain, 1957) as following:

Chlorophyll a $(\mathrm{mg} / \mathrm{l})=9.784 \times$ E662- $0.99 \times$ E644

Chlorophyll b $(\mathrm{mg} / \mathrm{l})=21.426$ x E644 -4.65 x E662

Carotenoids $(\mathrm{mg} / \mathrm{l})=4.695$ X E440 $-0.268($ Chlorophyll $\mathrm{a}+\mathrm{b})$

Where, $\mathrm{E}=$ Optical density at the wavelength indicated.

The concentration of pigments was then expressed in $\mathrm{mg} / \mathrm{g}$ fresh weightof leaves according to the following formula:

$\mathrm{mg} / \mathrm{g}=(\mathrm{mg} / \mathrm{l} \times$ dilution $) /($ sample weight $\mathrm{x} 1000)$

\section{Determination of total carbohydrates}

For determination of total carbohydrates content, a known weight of powdered samples were extracted from the dried terminal shoots in $1 \mathrm{~N}$ HClsolution for six hours at $100^{\circ} \mathrm{C}$ and filtered. The filtrate was raised to known volume. Total carbohydrate content was determined photometrically at $485 \mathrm{~nm}$ according to the phenol 
sulphuric acid method described by Dubois et al. (1956).Phenol reagent was prepared by adding $10 \mathrm{ml}$ of $\mathrm{H}_{2} \mathrm{O}$ to $90 \mathrm{ml}$ of the $5 \%$ phenol solution. The resultant solution should be colorless, but may develop a pale yellow color with time. Standard glucose solution was prepared by adding $50 \mathrm{mg}$ of glucose dissolved in water and raised to a final volume of $100 \mathrm{ml}$. A standard curve was prepared with a range of 20-150 $\mu \mathrm{l}$ ofglucose standard solution. A blank of distilled water was used. Five $\mathrm{ml}$ of phenol reagent were added to each tube and mixed thoroughly, then rapidly $5 \mathrm{ml}$ of $\mathrm{H}_{2} \mathrm{SO}_{4}$ were added to each tube. Samples were allowed to stand at room temperature for $30 \mathrm{~min}$ and the absorbance at $485 \mathrm{~nm}$ was recorded. The concentrations of glucose were plotted against the corresponding absorbance to generate a standard curve. The concentration of the unknown carbohydrate is determined graphically.

\section{Experimental design and statistical analysis of data}

The experiments were subjected to a completely randomized design. Analysis of variance (ANOVA) and Duncan's multiple range test (Duncan,1955), as modified by Snedecor and Cochron (1998) were used to analyze the obtained data. Each treatment of PBZ and ET had three replicated and each replicate consisted of 9 jars. The experiments were repeated twice. The differences between the averages of the recorded parameters for all treatments were tested for significance at the $5 \%$ level. The averages followed by the same letter are not significantly different at $p<0.05$.

\section{Results And Discussion}

Growth retardants are known to affect of morphological and physiological characters quality of the invitro producedplants. There are problems at acclimatization stage, in which the plantlets are very thin with low rate of survival when transfer to soil.After transferring multiple shoot buds into MS basal medium containing $2.0 \mathrm{mg} / \mathrm{l} \mathrm{BA}$ and various concentrations of PBZ and ET separately $(0.1,0.5,1.0$, and $2.0 \mathrm{mg} / \mathrm{l})$, the amount of PBZ and ET affected of multiple shoot formation, shoot length, leaves number, fresh and dry weights as presented in Table 1 and Figure 1.

Table 1. Effect of different concentrations of PBZ and ET in MS medium supplemented with BA (2.0 mg/l) on shoot multiplication, shoot length, leaves number and fresh and dry weights of Stevia after six weeks from culturing.

\begin{tabular}{|l|l|l|l|l|l|}
\hline Treatment & $\begin{array}{l}\text { No. of } \\
\text { shoots/explant }\end{array}$ & $\begin{array}{l}\text { Length of } \\
\text { shoots (cm) }\end{array}$ & $\begin{array}{l}\text { No. of } \\
\text { leaves/shoot }\end{array}$ & $\begin{array}{l}\text { Fresh weight } \\
\text { of shoot (g) }\end{array}$ & $\begin{array}{l}\text { Dry weight of shoot } \\
\text { (g) }\end{array}$ \\
\hline Control & $37.33 \mathrm{~b}$ & $7.37 \mathrm{a}$ & $7.00 \mathrm{a}$ & $2.03 \mathrm{bc}$ & $0.20 \mathrm{de}$ \\
\hline $\mathbf{0 . 1} \mathbf{~ m g / l ~ P B Z ~}$ & $48.00 \mathrm{a}$ & $6.5 \mathrm{ab}$ & $7.43 \mathrm{a}$ & $2.40 \mathrm{ab}$ & $0.27 \mathrm{bcd}$ \\
\hline $\mathbf{0 . 5} \mathbf{~ m g / l ~ P B Z ~}$ & $30.67 \mathrm{~b}$ & $5.63 \mathrm{bc}$ & $5.63 \mathrm{~b}$ & $2.83 \mathrm{a}$ & $0.39 \mathrm{a}$ \\
\hline $\mathbf{1 . 0} \mathbf{~ m g / l ~ P B Z ~}$ & $27.67 \mathrm{bc}$ & $4.93 \mathrm{~cd}$ & $4.30 \mathrm{c}$ & $1.87 \mathrm{bcd}$ & $0.29 \mathrm{abcd}$ \\
\hline $\mathbf{2 . 0} \mathbf{~ m g / l ~ P B Z ~}$ & $21.00 \mathrm{~d}$ & $4.00 \mathrm{de}$ & $3.87 \mathrm{~cd}$ & $1.43 \mathrm{~cd}$ & $0.26 \mathrm{bcd}$ \\
\hline $\mathbf{0 . 1} \mathbf{~ m g / l ~ E T ~}$ & $38.67 \mathrm{~b}$ & $6.13 \mathrm{~b}$ & $6.33 \mathrm{ab}$ & $2.20 \mathrm{ab}$ & $0.32 \mathrm{abd}$ \\
\hline $\mathbf{0 . 5} \mathbf{~ m g / l ~ E T ~}$ & $24.34 \mathrm{~cd}$ & $4.50 \mathrm{~d}$ & $4.33 \mathrm{c}$ & $2.83 \mathrm{a}$ & $0.36 \mathrm{ab}$ \\
\hline $\mathbf{1 . 0} \mathbf{~ m g / l ~ E T ~}$ & $20.33 \mathrm{de}$ & $3.13 \mathrm{ef}$ & $3.67 \mathrm{~cd}$ & $1.30 \mathrm{de}$ & $0.22 \mathrm{cde}$ \\
\hline $\mathbf{2 . 0} \mathbf{~ m g / l ~ E T ~}$ & $15.67 \mathrm{e}$ & $2.13 \mathrm{f}$ & $3.00 \mathrm{~d}$ & $0.70 \mathrm{e}$ & $0.14 \mathrm{e}$ \\
\hline
\end{tabular}

Means followed by the same letter within a column are not significantly different at $p>0.05$.

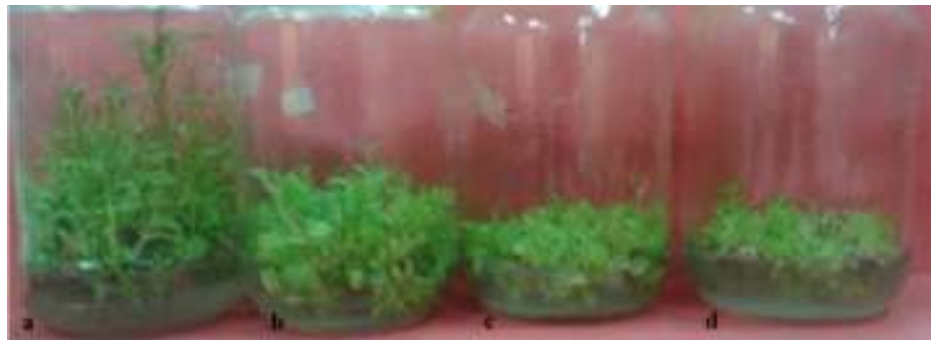

Figure 1. Multiple shoots formation of Stevia on MS medium supplemented with $2.0 \mathrm{mg} / \mathrm{l} \mathrm{BA}$ in addition to a) 0.1, b) 0.5, c) 1.0 and d) $2.0 \mathrm{mg} / \mathrm{l} \mathrm{PBZ}$.

Shoot proliferation was observed after six weeks from culturing. PBZ at the lower concentration of 0.1 $\mathrm{mg} / \mathrm{l}$ was significantly superior than the other concentrations; it gave the highest shoot number of 48.0 shoots/explant. These results are in agreement with that obtained by Anchalee and Bodhipadma (2012), who reported that low concentration of PBZ seems to have a power to enhance multiple shoot and plantlet formation in some species of Curcuma. Kongbangkerd and Yanaphan (2005) found that MS medium consisted of $0.1 \mathrm{mg} / \mathrm{l}$ PBZ was able to induce shoots of Curcma longa in vitro better than $0.5 \mathrm{mg} / \mathrm{l} \mathrm{PBZ}$. Also, some authors reported that PBZ enhanced cytokinin activities and induced adventitious shoot proliferation in Araceae (Werbrouck and Debergh, 1996). In addition, there are synergistic effects of PBZ and cytokinin, especially BA that enhancing 
shoot proliferation (Tefera and Wannakrairoj, 2006). PBZ induced suppression of gibberelin biosynthesis should have resulted in changes in hormonal constellation favorable for axillary bud initiation and branching as observed by Woodward and Marshall (1988). Such effect of intensification of cytokinin activity can result from the fact that growth retardants increase the contents of endogenous cytokinin (Rademacher, 2000). PBZ, like other growth retardants combined with cytokinin induced strong shoot proliferation (Ziv, 1990). Also the concentration of $0.1 \mathrm{mg} / \mathrm{l} \mathrm{ET}$ gave 38.67 shoots/explant, which is the highest number of shoots comparing to the other concentrations of ET. On the other hand, the highest concentration of $2.0 \mathrm{mg} / \mathrm{l}$ of PBZ and ET gave the lowest shoot number of 21.0 and 15.87 shoots/explant, respectively. On the other hand, the influence of PBZ and ET on shoot length in Stevia rebaudiana was clearly observed, where a gradual decrease in shoot length for all the treatments was noticed as compared to that of control, where the tallest shoots $(7.36 \mathrm{~cm})$ were recorded. Treatments with 1.0-2.0 mg/l PBZ gave significant reductions in stem length and fresh to dry weight ratios of shoots ofChrysanthemum (Elaine et al., 1990). Foster et al. (1991) reported that plant height was reduced by ET application. Alternatively, some of the applied ET may be translocated in the plant, as been demonstrated by Edgerton and Hatch (1972). Such translocated ET could then release ethylene in subapical elongation regions, leading to inhibited stem growth.

PBZ is a useful PGR that has been applied in agricultural systems for decades. PGRs are used on crops, such as rice and wheat to inhibit plant height as well as increase the number of tillers (Assueroet al., 2012). Average number of leaves ranged from 7.43 to 3.0. The highest number of leaves (7.43 and 7.0) was recorded with $0.1 \mathrm{mg} / \mathrm{l} \mathrm{PBZ}$ and the control. On the other hand, the lowest number of leaves was achieved on $2.0 \mathrm{mg} / \mathrm{l}$ ET, which gave 3.0 leaves /shoot. Regarding the mean shoot fresh and dry weights, the addition of PBZ and ET at $0.5 \mathrm{mg} / \mathrm{l}$ positively affected the obtained shoot weights, comparing to the different tested concentrations of PBZ and ET. It could be noticed that the fresh and dry weights were gradually increased with increasing the concentration from 0.1 to $0.5 \mathrm{mg} / \mathrm{l}$. Moreover, fresh weight rate was not varies significantly in the concentration of 0.1 to $0.5 \mathrm{mg} / \mathrm{l}$. While $0.5 \mathrm{mg} / \mathrm{l} \mathrm{PBZ}$ gave the maximum dry weight $(0.39 \mathrm{~g})$ of shoots, the highest concentration of PBZ (2.0 mg/l) led to a considerable decrease in shoot fresh weight $(1.43 \mathrm{~g})$. The highest fresh and dry weights of shoot (2.83 and $0.35 \mathrm{~g}$ ), regarding different concentrations of ET, was obtained with $0.5 \mathrm{mg} / \mathrm{l}$ ET, while the lowest fresh and dry weights of shoot $(0.7$ and $0.14 \mathrm{~g})$ were recorded at $2.0 \mathrm{mg} / \mathrm{l} \mathrm{ET}$. Inhibited gibberellin biosynthesis and increased cytokinin and abscisic acid content induced by triazoles might be the cause of increased root growth and corresponding dry or fresh weight in plants (Rajalekshmiet al., 2009). The obtained results indicate that increasing PBZ and ET concentrations resulted in a significant decrease in shoot number, shoot length, leave number and fresh and dry weights.

Root quality is an important index of in vitro plantlets quality and a critical factor for transplanting. adventitious rooting. Shoots formed roots on MS medium containing $2.0 \mathrm{mg} / \mathrm{l} \mathrm{IBA}$ and different concentrations of each of PBZ and ET separately (Table 2). It was observed that there is no significant difference in rooting percent among the different concentrations of PBZ and the control treatment, giving $88.8-100 \%$ of rooting. The higher dosage of ET (1.0 and $2.0 \mathrm{mg} / \mathrm{l})$ suppressed rooting percentage and gave $44.44 \%$ rooting, while 0.1 and $0.5 \mathrm{mg} / \mathrm{l} \mathrm{ET}$ were insignificantly different comparing to the other treatments. The highest roots number was

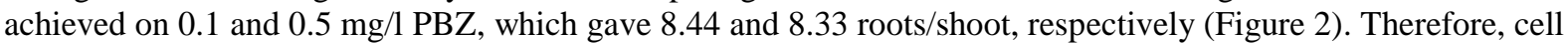
division may have been promoted, which in turn increased number of roots.

The increase in number of roots is necessary to keep shoot-root ratio in balance (Mukhtaret al., 1998). PBZ applied in combination with IBA increased the rooting capacity of cutting, by increasing root formation (Wiesman and Lavee, 1995). Depending on the plant species and the concentration applied, PBZ induce root anatomical and morphological modifications. It increased root diameter of rows and diameter of cortical cells (Burrows et al., 1992). PBZ increased root diameter in soybean by increasing the size of cortical parenchyma cells (Barnes et al., 1989). The increase in fine root development implies a more favorable root/crown balance and less stress in treated trees. Improved water status has been reported after treatment with PBZ (Swietlik and Miller, 1983 and Warren et al., 1991). Followed by $0.5 \mathrm{mg} / \mathrm{l}$ ET that gave 7.44 roots/shoot. These results are similar to that of Rossi et al. (2008) who found that pulverization of ET in the aboveground tissues of Pinus taeda seedlings caused thickening of tab roots, and an increase in the number of secondary roots in the middle and lower portion of the root system. ET affected adventitious rooting with IBA. Li et al. (2006) showed that ethylene treatment activated transcription of ARF19 in roots of Arabidopsis seedlings, which might provide an explanation for the effects of ET IBA combination. Krishanamoorthy (1972) and Roy et al. (1972) reported that ET promoted rooting, whereas Mullins (1972) showed that rooting was inhibited by ethylene. ET treatment promotes adventitious rooting of some herbaceous plants (Pan et al., 2002). Stepanovaet al. (2005) reported that IAA was accumulated by ethylene treatment. On the other hand, the highest average root length $(7.74 \mathrm{~cm})$ was obtained on MS medium without growth retardants (control). However, the average of root length was ranged from 6.14 to $2.86 \mathrm{~cm}$ for PBZ and ET concentrations. Data also revealed that root length was gradually decreased with increasing PBZ and ET concentrations. So, it is suggested that high concentrations of PBZ and ET cease reduction of root length and in contrast increased root thickness and number of roots, except the higher 
concentrations. In agreement with these results, Grazia (1988) reported that PBZ caused reduction of root length, especially at the end of the rooting phase when added to IBA.

Table 2. Effect of different concentrations of PBZ and ET in MS medium supplemented with IBA (2.0 mg/l) on rooting formation of Stevia after four weeks from culturing.

\begin{tabular}{|l|l|l|l|}
\hline Treatment & $\begin{array}{l}\text { Rooting } \\
\%\end{array}$ & No. of roots/shoot & Length of root (cm) \\
\hline Control & $100.0 \mathrm{a}$ & $6.00 \mathrm{c}$ & $7.74 \mathrm{a}$ \\
\hline $\mathbf{0 . 1} \mathbf{~ m g / l ~ P B Z ~}$ & $100.0 \mathrm{a}$ & $8.44 \mathrm{a}$ & $6.14 \mathrm{~b}$ \\
\hline $\mathbf{0 . 5} \mathbf{~ m g / l ~ P B Z ~}$ & $100.0 \mathrm{a}$ & $8.33 \mathrm{a}$ & $6.08 \mathrm{~b}$ \\
\hline $\mathbf{1 . 0} \mathbf{~ m g / l ~ P B Z ~}$ & $88.8 \mathrm{a}$ & $6.33 \mathrm{bc}$ & $4.93 \mathrm{~cd}$ \\
\hline $\mathbf{2 . 0} \mathbf{~ m g / l ~ P B Z ~}$ & $88.8 \mathrm{a}$ & $5.00 \mathrm{~cd}$ & $2.91 \mathrm{e}$ \\
\hline $\mathbf{0 . 1} \mathbf{~ m g / l ~ E T ~}$ & $88.8 \mathrm{a}$ & $5.22 \mathrm{~cd}$ & $5.66 \mathrm{bc}$ \\
\hline $\mathbf{0 . 5} \mathbf{~ m g / l ~ E T ~}$ & $77.78 \mathrm{ab}$ & $7.44 \mathrm{ab}$ & $5.48 \mathrm{bc}$ \\
\hline $\mathbf{1 . 0} \mathbf{~ m g / l ~ E T ~}$ & $44.44 \mathrm{c}$ & $5.11 \mathrm{~cd}$ & $4.37 \mathrm{~d}$ \\
\hline $\mathbf{2 . 0} \mathbf{~ m g / l ~ E T ~}$ & $44.44 \mathrm{c}$ & $4.33 \mathrm{~d}$ & $2.86 \mathrm{e}$ \\
\hline
\end{tabular}

Means followed by the same letter within a column are not significantly different at $p>0.05$.

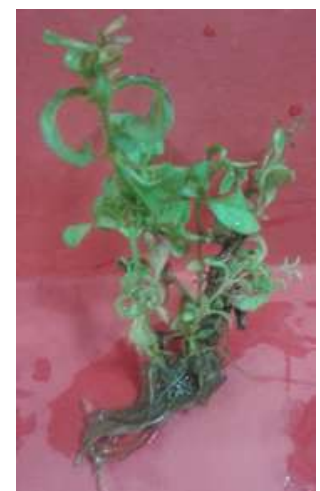

Figure 2. Root development of Stevia in MS medium supplemented with $2.0 \mathrm{mg} / \mathrm{l} \mathrm{IBA}$ in addition to $0.1 \mathrm{mg} / \mathrm{l}$ PBZ.

Chlorophyll content is one of the indirect markers of the efficiency of the photosynthetic apparatus, for all chlorophyll and not only that takes part in photosynthesis. Photosynthesis is a physiological marker related to vitro plantquality (Borkowska, 2003). The effect of PBZ and ET treatments on chlorophyll a, chlorophyll b, carotenoids and carbohydrates content were evaluated (Table 3). It was clear that leaf chlorophyll a and b, carotenoids and carbohydrates content were increased in treated plantlets at the different treatments compared with the control. The highest amount of chlorophyll $\mathrm{a}$ and $\mathrm{b}$ and carbohydrates were recorded on MS medium supplemented with $2.0 \mathrm{mg} / \mathrm{l} \mathrm{PBZ}$; they reached $0.083,0.179$ and $1.715 \mathrm{mg} / \mathrm{g}$, respectively. On the other hand, the control had the lowest amount of chlorophylla and $b$, carotenoids andcarbohydratescontent were found on MS medium withoutsupplementations (control), which recorded 0.010, 0.030, 0.061 and $0.024 \mathrm{mg} / \mathrm{g}$, respectively. Fletcheret al. (2000) proposed that PBZ as one in triazol group stimulates cytokinin synthesis that enhances chloroplast differentiation, chloroplast differentiation, chlorophyll biosynthesis and prevents chlorophyll degradation. Nouriyaniet al. (2012) reported that an increase in PBZ concentrations increased chlorophyll content significantly in two wheat cultivars. Also, Pinhero and Fletcher (1994) observed an increase in chlorophyll and carotenoid pigments after treatments with the triazole compound PBZ in maize seedlings. Aboelfazlet al. (2013) reported that treating plants of banana with PBZ increases the total leaf chlorophyll content when compared with the control treatment. Samani (2104) results showed that PBZ concentration had significant effect on leaf chlorophyll content. Whereas, the concentration of $0.5 \mathrm{mg} / \mathrm{l} \mathrm{PBZ}$ gave the highest carotenoids content $(0.122 \mathrm{mg} / \mathrm{g})$. Youssef and Abd El-Aal (2013) reported that PBZ significantly increased total carbohydrates and total chlorophylls content inTabernaemontanacoronaria as compared with untreated plants. Regarding the effect of ET, the results indicated that the ET levels had significant effect on chlorophyll a and $\mathrm{b}$, carotenoids and carbohydrates. Leaf chlorophyll $\mathrm{a}$ and $\mathrm{b}$ were all significantly higher than control. The highest chlorophyll a and b contents was recorded on MS medium supplemented with 2.0mg/l ET (0.062 and $0.171 \mathrm{mg} / \mathrm{g}$, respectively), followed by $1.0 \mathrm{mg} / \mathrm{l} \mathrm{ET}$, which gave 0.42 and $0.129 \mathrm{mg} / \mathrm{g}$, respectively. Decreasing the concentration of ET caused decreasing in the level of chlorophyll a and b. Wei et al. (2006) reported that ET causes photosynthesis improvement. On the other hand, the lowest cholorophylla and b content was achieved on the control medium. Carotenoids and carbohydrates were affected by ET concentrations, as $0.5 \mathrm{mg} / \mathrm{l} \mathrm{ET}$ recorded the highest carotenoids and carbohydrates content $(0.179$ and $1.814 \mathrm{mg} / \mathrm{g}$, respectively), while MS 
medium (control) gave 0.061 and $0.024 \mathrm{mg} / \mathrm{g}$, respectively. The results cleared that raising the levels of ET used increased chlorophyll $\mathrm{a}$ and $\mathrm{b}$ and carotenoids content in the leaves.

Table 3.Effect of different concentrations of PBZ and ET on the contents of chlorophyll a and b, carotenoids and carbohydrates of Stevia.

\begin{tabular}{|c|c|c|c|c|}
\hline Treatments & Chl. a (mg/g) & Chl. b (mg/g) & Carotenoids (mg/g) & Carbohydrates (mg/g) \\
\hline Control & $0.010^{\mathrm{e}}$ & $0.030^{\mathrm{g}}$ & $0.061^{\mathrm{e}}$ & $0.024^{\mathrm{i}}$ \\
\hline $0.1 \mathrm{mg} / \mathrm{l} \mathrm{PBZ}$ & $0.020^{\mathrm{d}}$ & $0.040^{f}$ & $0.082^{\mathrm{d}}$ & $0.046^{\mathrm{h}}$ \\
\hline $0.5 \mathrm{mg} / \mathrm{l} \mathrm{PBZ}$ & $0.043^{\mathrm{b}}$ & $0.130^{\mathrm{b}}$ & $0.112^{\mathrm{c}}$ & $1.082^{\mathrm{b}}$ \\
\hline $1.0 \mathrm{mg} / \mathrm{l} \mathrm{PBZ}$ & $0.038^{\mathrm{b}}$ & $0.166^{\mathrm{a}}$ & $0.122^{\mathrm{b}}$ & $1.073 \mathrm{~b}$ \\
\hline $2.0 \mathrm{mg} / \mathrm{l} \mathrm{PBZ}$ & $0.083^{\mathrm{a}}$ & $0.179^{\mathrm{a}}$ & $0.073^{\mathrm{d}}$ & $1.715^{\mathrm{a}}$ \\
\hline $0.1 \mathrm{mg} / \mathrm{l}$ ET & $0.031^{\mathrm{c}}$ & $0.068^{\mathrm{d}}$ & $0.058^{\mathrm{e}}$ & $0.097^{\mathrm{g}}$ \\
\hline $0.5 \mathrm{mg} / \mathrm{l}$ ET & $0.034^{\mathrm{c}}$ & $0.088^{\mathrm{c}}$ & $0.179^{\mathrm{a}}$ & $1.814^{\mathrm{a}}$ \\
\hline $1.0 \mathrm{mg} / \mathrm{l} \mathrm{ET}$ & $0.042^{\mathrm{b}}$ & $0.129^{\mathrm{b}}$ & $0.059^{\mathrm{e}}$ & $1.068^{\mathrm{c}}$ \\
\hline $2.0 \mathrm{mg} / \mathrm{l}$ ET & $0.062^{\mathrm{a}}$ & $0.171^{\mathrm{a}}$ & $0.082^{\mathrm{d}}$ & $0.670^{\mathrm{d}}$ \\
\hline
\end{tabular}

Means followed by the same letter within a column are not significantly different at $p>0.05$.

\section{Acclimatization stage}

A major limitation in large scale application of micropropagation technology is high mortality experienced by in vitro raised plants during laboratory to land transfer. Micropropagated plants on being transferred to ex vitro conditions are exposed to altered temperature, light intensity and water stress conditions, so need acclimatization for successful establishment and survival of plantlets (Chandra et al., 2010). It is evaluated by percentage of the surviving plants, which was clearly affected by the different treatments of PBZ. The results in Table 4 indicated that acclimatization of rooted shoots in the new environment in the greenhouse ranged between 40 and $85 \%$. The highest percentage of survived plants with new leaves was achieved $85 \%$, when cultured on medium with PBZ at $2.0 \mathrm{mg} / \mathrm{l}$ (Figure 3), followed by $1.0 \mathrm{mg} / \mathrm{l}$, which gave $70 \%$ survival percentage. On the other hand, the survival percentage of plants was the lowest $(40 \%)$, when shoots were cultured on MS medium without supplementation of PBZ (control).

Table 4.Effect of PBZ and ET on survival percentage of Steviaplantlets during acclimatization stage.

\begin{tabular}{|l|l|}
\hline Treatment & Survival percentage\% \\
\hline control & 40 \\
\hline $0.1 \mathrm{mg} / \mathrm{l} \mathrm{PBZ}$ & 55 \\
\hline $0.5 \mathrm{mg} / \mathrm{l} \mathrm{PBZ}$ & 65 \\
\hline $1.0 \mathrm{mg} / \mathrm{l} \mathrm{PBZ}$ & 70 \\
\hline $2.0 \mathrm{mg} / \mathrm{l} \mathrm{PBZ}$ & 85 \\
\hline $0.1 \mathrm{mg} / \mathrm{l} \mathrm{ET}$ & 55 \\
\hline $0.5 \mathrm{mg} / \mathrm{l} \mathrm{ET}$ & 60 \\
\hline $1.0 \mathrm{mg} / \mathrm{l} \mathrm{ET}$ & 70 \\
\hline $2.0 \mathrm{mg} / \mathrm{l} \mathrm{ET}$ & 75 \\
\hline
\end{tabular}

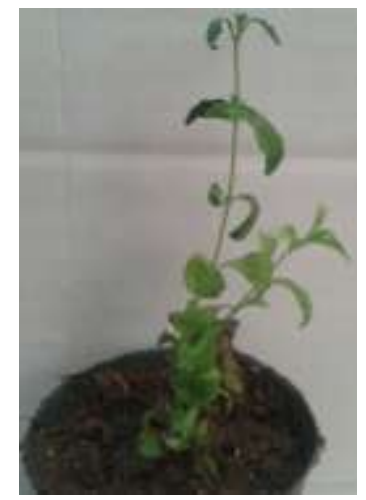

Figure (3).Hardened Stevia plant under greenhouse conditions.

According to many sources, the growth retardants increase the ability of plants to overcome acclimatization phase. Eliassonet al. (1994) noted that survival of Prunusserotirina four weeks after transfer to the soil was significantly improved by PBZ. Similarly, survival of Philodendron that had been treated with PBZ during proliferation was much better (100\%), compared with control (78\%) (Ziv, 1990). Robert and Mattews (1995) reported that Chrysanthemum "Pennile Reel" treated with PBZ in rooting medium had greater resistance 
to desiccation. Fernandeset al. (2004) reported that to improve survival rate of the in vitro plants to soil or field conditions, the use of chemicals; such as plant growth regulators are of great interest. Moreover, the recent development of highly active growth retardants enhances the potential uses of chemical regulators. Among them, PBZ is widely used. It could be noticed that the survival frequency from the plantlets hardened was gradually increased with increasing the concentration from 0.1 to $2.0 \mathrm{mg} / \mathrm{l} \mathrm{PBZ}$. Regarding the effect of ET treatments on plant growth in the acclimatization stage, the survival percentage after transplantation in the greenhouse was different for the different pretreatments in rooting stage (Table 4). Inexpressive survival was ranged from 40 to $75 \%$. The highest rate $(75 \%)$ in acclimatization occurred when the plantlets were treated with ET at $2.0 \mathrm{mg} / \mathrm{l}$ during the in vitro rooting stage. However, the lowest rate $(40 \%)$ was observed in untreated plantlets (control). This result is similar to that of Scagel and Linderman (2001) who concluded that ET treatment induced a reduction in seedling height, an increase in stem caplier, and growth of new roots in the nursery with a significant positive correlation with survival after planting. An increase of ET spray formulation reduced overall stem growth and increased cell elongation of the aboveground plant tissues. These morphological changes are expected during seedling hardening according to Jacobs and Landes (2009). Joao et al. (2013) reported that the use of ET reduced aboveground growth and significantly increase the root biomass of Parchystromalongifolium, validating its use to promote the morphological changes expected during seedling in nurseries. Based on the production of above ground tissue and increase root biomass,Parchystromalongifoliumseedling root system may act as a storage organ in response to ET application, the increments express growth rate as a function of time and reflect growth vigor (Joao et al., 2013). It should be noted that increased levels of ET are promoting a quadratic increase in the percentage of surviving plants during the acclimatization stage.

\section{Conclusion}

In conclusion, PBZ and ET significantly enhanced the vegetative and reproductive characteristics of Stevia both in vitro and ex vitro. The results also indicated that the application of PBZ had the greatest effect on the development ofStevia shoot and rootin vitroand improvement of the survival during acclimatization.According to the results of the present study, it is effective to use such treatments in the micropropagation procedure to increase the ability of in vitro produced plantlets after their transfer to the soil to withstand the acclimatization stress.

\section{References}

[1]. Aboelfazl, L., M. Sajad, B. Reza and T. Nourbakhsh (2013).Role of paclobutrazol on vegetative and sexual growth of plants. International Journal of Agriculture and Crop Sciences, 5: 958-961

[2]. Alves, S.A.O., O.F.Lemos, B.G.Santos Filho and A.Silva (2011). In vitro embryo rescue of interspecific hybrids of oil palm (Elaeisoleifera x Elaeisguineensis).J. Biotechnol. Biodiver., 2: 1-6

[3]. Anchalee, J and K. Bodhipadma (2012). Low concentration of paclobutrazol induced multiple shoot and plantlet formation in Amethyst curcuma. The Journal of KMUTNB, 22: 505-510

[4]. Arpita, D., S. Gantaite and N. Mandal (2011).Micropropagation of an elite medicinal plant: Stevia rebaudiana Bert. Int. J. Agric. Research, 6: 40-48

[5]. Assuero, S.G., M. Lorenzo, N.M.P. Ramfres, L.M. Velazquesand and J.A. Tognetti (2012). Tellering promotion by paclobutrazol in wheat and its relationship with plant carbohydrate status. N. Z. J. Agri. Res., 55: 347-358

[6]. Barnes, A.M., R.H. Walser and T.D. Davis (1989). Anatomy of Zea mays and Glycine max seedlings treated with triazole plant growth regulators. Biol. Plant., 31: 370-375

[7]. Borkowska, B. (2003). Fotosyntezajako marker fizjologicznyjakoscikulturpedowych I otrzymanychroslin. Biotechnologia, 62: 3038

[8]. Burrows, G.E., T.S. Boag and W.P. Stewart (1992).Changes in leaf, stem, and root anatomy of Chrysanthemum cv. Lillian Hoek following paclobutrazol application. Journal of Plant Growth Regulation, 11: 189-194

[9]. Chandra, S., R. Bandopadhyay, V. Kuma andR. Chandra (2010). Acclimatization of tissue cultured plantlets: fromlaboratory to land. Biotechnol.Lett., 32:1199-1205

[10]. Debnath, M. (2008). Clonal propagation and antimicrobial activity of an endemic medicinal plant Stevia rebaudiana.J. Med. Plants Res., 2: 45-51

[11]. Dubois, M., K.A. Gilles, J.K. Hamilton, P.A. Rebers and F. Smith (1956).Colorimetric method for determination of sugars and related substances. Ann. Chem., 26: 350-356.

[12]. Duncan, D. B. (1955). Multiple ranges and multiple F- test. Biometrics, 11: 1-24

[13]. Edgerton, L.J. and A.H. Hatch (1972).Absorption and metabolism of $\mathrm{C}^{14}$ (2-Chloroethyl) phosphonic acid in apples and cherries. J. Amer. Soc. Hort. Sci., 97: 112-115

[14]. Elaine, F.S., V.R. Andrew and M. John (1990).The preparation in vitro of Chrysanthemum for transplantation to soil. Plant Cell Tissue and Organ Culture, 21: 133-140

[15]. Eliasson, M.K., C.A. Beyl, and P.A. Barker (1994).In vitro responses and acclimatization of Prunusserotina with paclobutrazol. Journal of Plant Growth Regulation, 13: 137- 142

[16]. Fadeel, A.A. (1962).Location and properties of chloroplasts and pigment determination in roots.Physoil. Plant., 15:130-147

[17]. Fernandes, J.A., L. Balenzategui, S. Banon and J.A. Franco(2004). Induction of drought tolerance by paclobutrazol and irrigation deficit in Phillyreaangustifolia during the nursery period.ScientiaHorticulturae, 107: 277- 283

[18]. Fletcher, R.A., A. Gilly, N. Sankhla and T.D. Davis (2000).Triazoles as plant growth regulators and stress protectants. Horticultural Review, 24: 55- 138

[19]. Foster,K., D. Reid and J. Taylor (1991). Tellering and yield responses to ethephon in three barley cultivars. Crop Sci., $31:$ 130-135 
[20]. Glady, J.E., N. Suzlang and E.S. Runkle (2007).Effect of ethephon on stock plant management of Coreopsis verticillata, Dianthus caryophyllus, and Veronica longifolia.Hort Science, 42:1616-1621

[21]. Graebe, J.E. (1987). Giberellin biosynthesis and control. Annual Review in Plant Physiology, 38: 419-465

[22]. Grazia, M. (1988).The effect of paclobutrazol on in vitro rooting, transplant establishment and growth of fruit plants. Plant Growth Regulation, 7: 237-247

[23]. Grossman, K. (1992). Plant growth retardants: Their mode of action and benefit for physiological research, p.788-797. In: C. M. Karssen, L.C. Van Loon and D. Vreugdenhl (eds). Progress in Plant growth regulation. Kluwer Academic Publ., Dodrecht, Netherlands

[24]. Hazarika, B.N. (2006). Morpho-physiological disorders in in vitro culture of plants. Sci. Hort., 108:105-120.

[25]. Jacobs, D. F. and T. D. Landes (2009).Hardening. In: Dumroses, R.K., T.Luna,T.D. Landis (Eds). Nursery manual for native plants, guide for tribal nurseries. Washington, USA. 1: 217: 239

[26]. Jain, P., S. Kachhwaha and S.L. Kothari (2009). Improved micropropagation protocol and enhancement in biomass and chlorophyll content in Stevia rebaudianaBertoni by using high copper levels in the culture medium, Sci. Hort., 119: $315-319$

[27]. Joao, A.L.D., U. C. Malavasi, M. M. Malavasi and D.F. Jacobs (2013).Effect of ethephon on hardening of Pachystromalongifolium seedlings.RevistaArvor, Vicosa-MG., 37: 401-407

[28]. Kidd, H. and D.R., James (1991). The Agrochemicals Handbook, Third Edition. Royal Society of Chemistry Information Services. Cambridge, UK. 10-2 (AS update)

[29]. Kongbangkerd, A and W. Yanaphan (2005). Effect of light, sucrose and plant growth retardants on in vitromicrorhizome induction of Curcuma longaL. "NU SceinceJounal, 2: 73-86

[30]. Krishanamoorthy, H.N. (1972). Effect of ethrel, auxins and maleic hydracide on the rooting of Mung bean hypocotyls cuttings.ZpflanzenPhsiol., 66: 273- 276

[31]. Kumar, K. and I.U.Rao(2012).Morphophysiological problems in acclimatization of micropropagated plants inex vitro contitions-a Reviews. J. Ornam. Hort. Plants, 2:271-283.

[32]. Li, J., X. Dai and Y. Zhao (2006). A role for auxin response factor 19 in auxin and ethylene signaling in Arabidopsis. Plant Physiol., 140: 899- 908

[33]. Miyazaki, Y. andH.Wantenabe(1974). Studies on the cultivation of Stevia rebaudianaBertoni on the propagation of plant.J. Trop. Agric., 17: 154-157.

[34]. Mukhtar, A.A.I., M.H. Laghari and A. Hiday(1998). Effect of growth regulators on rooting in softwood cuttings of guava under mist condition.Sarhad J. Agri. Res., 14: 423-425

[35]. Mullins, M.G. (1972). Auxin and ethylene in adventitious root formation in Phaseohusaureus(Roxb.). In D.J. Caff, ed,Plant Growth Substances, Springer-Verlag, Berlin

[36]. Murashige, T. and Skoog F. (1962). A revised medium for rapid growth and bioassays with tobacco tissue culture. Physiol. Plant., 15: 473-497

[37]. Nakamura S.and Y. Tamura (1985). Variation in the main glycosides of Stevia (Stevia rebaudiana).Jpn. J. Trop. Agric.,29: 109-116

[38]. Nouriyani, H., E. Majidi, S.M. Seyyednejad, S.A. Siadat and A. Naderi (2012). Effect of paclobutrazol under different levels of nitrogen on some physiological traits of two wheat cultivars (Triticumaestivum L.). World App. Sci. J., 16 : 01 - 06

[39]. Pan, R., J. Wang and X. Tian (2002).Influence of ethylene on adventitious root formation in Mung beanhypoctyl cutting.Plant Growth Regul., 36: 135-139

[40]. Pinhero, R. and R.A. Fletcher (1994).Paclobutrazol and ancymidol protect corn seedlings from high and low temperature stresses. Plant Growth Regul., 15: 47- 53

[41]. Rademacher, W. (2000). Growth retardants: Effects on gibberellin biosynthesis and other metabolic pathways. Ann. Rev. Plant Physiol. Plant Mol. Biol., 51:501-531.

[42]. Rajalekshmi, K.M., C. Abdul Jaleel, M.M. Azoz and R. Panneerselvam (2009).Effect of triazole growth regulators on growth and pigment contents in Pletranthusaromaticus and Plectranthusvettiveroids. Advances in Biological Research, 3: $117-122$

[43]. Roberts, A.V., S. Walker., I.Horan, E.F. Smith and J. Mottley (1992). The effects of growth retardants, humidity and lighting at stage III on stage IV of micropropagation inChrysanthemum and rose.ActaHortic., 319: 153-158

[44]. Rossi, V.L.,C.V.T. Amarante,F.D. Fleig (2008). Crescimento e qualidade de mudas de Pinus taeda L. submetidas à poda química de raízes. Ciência Florestal, 18,(4): 435-442

[45]. Roy, B.N., R.N. B.A. Su and T. Bose (1972).Interaction of auxins with growth-retarding, inhibiting and ethylene-producing chemicals in rooting of cuttings. Plant Cell Physiol., 13: 1123-1127

[46]. Samani, R.B. (2014). Effects of paclobutrazol on vegetative and reproductive characteristics ofpeach (Prunuspersica L.) cv. 'Kardi'. Agricultural Communications, 2: 37-42

[47]. Savita, S., K.Sheela, S.Sunanda, A.Shankar and P.Ramakrishna(2004).Stevia rebaudiana-a functional component for food industry. J. Hum. Ecol., 15: 261-264

[48]. Scagel, C.F. and R.G. Linderman ( 2001). Modification of root IAA concentrations, tree growth, and survival by application of plant growth regulating substances to container-grown conifers. New Forests, 21:159-186

[49]. Snedecor, G.W. and W.G. Cochron, (1998).Statistical Methods.Iowa State University Press, Ames, Iowa, USA

[50]. Sopher, C.R., M. Krol, N.P.A. Huner, A.E. Moore and R.A. Fletcher(1999). Chloroplastic changes associated with paclobutrazol induced stress protection in maize seedlings. Can. J. Bot., 66: 279-290

[51]. Stepanova, A.N., J.M. Hoyt, A.A. Hamilton and J.M. Alonso (2005). A link between ethylene and auxin uncovered by the characterization of two root specific ethylene insensitive mutants in Arabidopsis. Plant Cell, 17: 2230- 2242

[52]. Summon, M.H., M. Mostofa, M.S. Jahan, M.E.H. Kayesh and M.A.Haque (2008). Comparative efficacy of powdered form of Stevia (Stevia rebaudianaBertoni) leaves and glimepiride in induced diabetic rats. Bangl. J. Vet. Med.,6: 211-215

[53]. Swietlik, D. and S.S. Miller (1993).The effect of paclobutrazol on growth and response to water stress of apple seedlings.J.Amer. Soc. Hort. Sci., 108: 1076- 1080

[54]. Tanaka, O. (1982). Steviol-glycosides: new natural sweeteners. Trend Anal. Chem., 1: 246-248

[55]. Tefera,W. and S.Wannakrairoj (2006). Synergistic effects of some plant growth regulators on invitro shoot proliferation of Korarima [Aframonum corrorima (Braun)Jansen].African Journal of biotechnology, 5:1894-1901

[56]. Thiyagarajan, M. and P. Venkatachalam (2012). Large scale in vitro propagation of Stevia rebaudiana (Bert.) for commercial application: pharmaceutically important and antidiabetic medicinal herb. Ind. Crop. Prod., 37:111-117

[57]. Toyoda, K.,H. Matsui, T. Shoda, C. Uneyama,K. Takada and M. Takahashi (1997). Assessment of the carcinogenicity of stevioside in F 344 rates.Food Chem. Toxicol., 35:597-603

[58]. Uddin, M.S., M. Chowdhury, M. Khan, M.B.Uddin, R. Ahmed and M.A.Baten (2006).In vitro propagation of Stevia rebaudianaBert in Bangladesh.Afr. J. Biotechnol.,5: 1238-1240 
[59]. Von Wettstein, D. (1957). Chlorophyll-letale und der submikroskopische frmwechsel der plastiden. Exp. Cell Res., 12:427-433

[60]. Warren, S.L., F.A. Blazich and M. Thetford (1991).Whole-plant response of selected woody landscape species to uniconazole. J. Environ. Hort., 9:163-167

[61]. Wei, Y., C.Hu, Z.Deng and Y.Li (2006).Differential gene expression in suger cane regulated by ethephon at early growth stage.Suger Tech., 8: 306-308

[62]. Werbrouck, S.P.O and P.C. Debergh (1996).Imidazole funqicides and paclobutrazol enhance cytokinin-induced adventitious shoot proliferation inAraceae. Journal of Plant Growth Regulation, 15:81-85

[63]. Wettstain, D. (1957).Chlorophyll, letal under submikroSvopischeformmechSallder- plastiden.Exptl. Cell Rec., 12:427-433.

[64]. Wiesman, Z. and S. Lavee (1995).Enhancement of IBA stimulatory effect on rooting of olive cultivar stem cutting.ScientiaHorticulturae, 65: 189-198

[65]. Woodward, E.J. and C. Marshall (1988).Effect of plant growth regulators and nutrient supply on tiller bud outgrowth in barly (Hordeumdistichu L.). Ann. Bot., 61: 346- 354

[66]. Youssef, A.S. and M.M. Abd El-Aal (2013). Effect of paclobutrazol and cycocel on growth, flowering, chemical composition and histological features of potted Tabernae montana coronariaStapfplant. Journal of Applied Sciences Research, 9:5953-5963

[67]. Ziv,M.(1990). The effect of growth retardants on shoot proliferation and morphogenesis in liquid cultured gladiolus plants. Acta Hort., 280: 207-214 